\title{
Assessment of the technical condition of a marine diesel engine based on the analysis of the exhaust gases chemical composition
}

\begin{abstract}
In the article, the concept of technical diagnostics in relation to marine engines was characterized. The compression ignition piston engine was presented as a diagnostic object. The next part of the article discusses the composition of exhaust gases with particular emphasis on compounds harmful to the environment. The available test methods for exhaust composition are also briefly described by means indication of the engine and exhaust gas analyzer. The reduction of emission of harmful compounds in the exhaust gases is also described in the article. The main part of the article presents the research object, i.e. the marine diesel engine piston and the exhaust gases analyzer, as well as tests carried out. The tests were performed for the engine in working order and inefficient condition in order to compare them with the simulated damages of injection pump and turbocharger. The article was completed conclusions.
\end{abstract}

Key words: technical diagnostics, exhaust composition, engine indication, exhaust gas analysis, marine diesel engine

\section{Introduction}

As a result of the marine engine operation, its elements wear. Therefore, it is very important to constantly diagnose it in order to keep the engine in the best possible technical condition. The construction of the engine and the physicochemical processes occurring during the engine operation process are used during the diagnosis. The most useful parameters of work processes include, among others, combustion, fuel supply, and air supply. In addition to the parameters of the work processes, physicochemical parameters such as pressure, temperature, vibrations and exhaust composition are also important [1].

Examination of the technical condition of the engine belong to the group of control tests, which include research and measurements that enable the assessment of the engine's operation and determination of the wear of its components. Therefore, there are many ways to assess the technical condition of a marine piston engine. One of them is the analysis of the chemical composition of exhaust gases presented in this article.

\section{Marine diesel engine as a diagnostic object}

The marine engine is characterized by a complicated construction, which consists of many functional systems $[5,10]$.

The quantity and complex structure of these systems makes the ship engine a special object of technical diagnostics. Each of them has a very large impact on the reliability of the engine and the safety of people and the ship.

\section{Exhaust gas composition in marine diesel engines}

Exhaust gases are created as a result of a complex combustion process with intense heat discharge. In addition, there is also the emission of harmful compounds along with other combustion products. Nitrogen oxides $\left(\mathrm{NO}_{\mathrm{x}}\right)$, sulfur oxides $\left(\mathrm{SO}_{\mathrm{x}}\right)$, hydrocarbons $\left(\mathrm{C}_{\mathrm{n}} \mathrm{H}_{\mathrm{m}}\right)$, particulates $(\mathrm{PM})$, carbon dioxide $\left(\mathrm{CO}_{2}\right)$, carbon monoxide $(\mathrm{CO})$, aldehydes ( $\mathrm{RCHO}$ ) are considered to be the basic components of the exhaust [2].

These compounds can take the gaseous, liquid or solid form. The composition of the exhaust depends on the technical condition of the engine, fuel quality and air parameters $[6,7,9]$.

\section{Diagnosing the technical condition of the marine diesel engine}

\subsection{Exhaust gas analyzers}

Flue gas analyzers allow for accurate evaluation and analysis of exhaust fumes. These analyzers must be properly selected and used in accordance with the control tests. The exhaust gas analyzers can be distinguished $[4,8]$ :

- non-dispersive analyzers - mainly used to determine the content of carbon oxides and carbon dioxide in engines,

- flame-ionization - are used to analyze the concentration of hydrocarbons,

- chemiluminescence - allows the examination of the exhaust gas composition in terms of content $\mathrm{NO}_{\mathrm{x}}$.

- magnetic - in this case, the oxygen content tests in the exhaust gas are carried out.

\section{Exhaust gas analysis}

\subsection{Methodology for determining the amount of air supplied to the fuel}

The amount of air supplied to burn fuel is one of the most important factors affecting the actual course of the combustion process. The appropriate air content causes the fuel combustion process is complete. There are no harmful compounds in the exhaust.

In order to achieve complete and total combustion of fuel, the air supplied to the cylinder should be in excess. The theoretical amount of air is not enough due to the limited time of air flow through the combustion space and improper fuel grinding.

Excess air is determined by the excess air factor $\lambda$, which can be defined as the ratio of the amount of air supplied to the amount theoretically needed to completely burn fuel [11] and is determined by the equation:

$$
\lambda=\frac{\mathrm{L}}{\mathrm{L}_{\mathrm{t}}}
$$

where: $\mathrm{L}$ - the actual mass of dry air in which the fuel is burned, $\mathrm{L}_{\mathrm{t}}-$ theoretical demand for dry air.

The excess air factor $\lambda$ depends on the quality of the fuel and its fragmentation, the structure of the combustion space and the method of feeding fuel and air to the combus- 
tion space. It is closely related to total and incomplete combustion. As a result of the low coefficient $\lambda$, incomplete combustion of fuel occurs, which causes thermal losses. On the other hand, too high value of the excess air coefficient causes incomplete combustion resulting in an increase in the amount of heat. To determine the air excess coefficient $\lambda$, the formula (1) is used, which takes the form for incomplete combustion:

$$
\lambda=\frac{21 \% \mathrm{O}_{2}}{21 \% \mathrm{O}_{2}-\mathrm{U}_{\mathrm{O} 2}}
$$

where: $\mathrm{U}_{\mathrm{O} 2}$ - the amount of unburned air (oxygen), (21\% $\mathrm{O}_{2}-\mathrm{U}_{\mathrm{O} 2}$ ) - amount of air (oxygen) consumed during combustion.

The excess air ratio $\lambda$ is calculated assuming that the amount of excess air is proportional to the measured proportion of oxygen in the exhaust gas. Under normal conditions, the molar ratio of oxygen in the air is $21 \%$.

In order to analyze the composition of exhaust gases, it is necessary to use graphs showing the relationships between components of exhaust gases and illustrating the excess air ratio, among others Ostwald's chart. If the percentage chemical composition of the fuel is known ( $\mathrm{c} \%$ carbon, $\mathrm{h} \%$ hydrogen, $\mathrm{o} \%$ oxygen, $\mathrm{s} \%$ sulfur in $\%$ nitrogen) and volume proportions of individual exhaust gas compounds $(b \%$ carbon dioxide, $\mathrm{t} \%$ carbon monoxide, $\mathrm{ns} \%$ nitrogen and os $\%$ oxygen), an equation for the balance of oxygen contained in the exhaust components and the air supplied for combustion may be used:

$$
(1+b) \cdot b+(0.605+a) \cdot t+o_{s}=21 \%
$$

where the fuel differentiator is defined by the formula:

$$
a=2.37 \frac{h-0.125(o-s)}{c}
$$

The equation of the simplified percentage balance of exhaust gases is expressed by the formula:

$$
\mathrm{b}+\mathrm{t}+\mathrm{O}_{\mathrm{s}}+\mathrm{n}_{\mathrm{s}}=100 \%
$$

The maximum percentage of carbon monoxide is calculated from the formula:

$$
\mathrm{t}_{\max }=\frac{21}{0.605+\mathrm{a}}
$$

\section{Reduction of emission of harmful compounds in the exhaust gases}

\subsection{The primary method}

The main feature of the primary method of reducing the emission of harmful compounds is to prevent the formation already during combustion in the combustion chamber [3].

This method intervenes in the fuel combustion process and requires engine design changes.

\subsection{The secondary method}

This method is based on purification of exhaust gases after the fuel combustion process. The advantage of these methods is better efficiency in the reduction of nitrogen oxides as opposed to primary methods.

One of the best and most effective methods is the method of selective catalytic reduction (SCR) [3].

\section{Research on the laboratory test stand}

The engine test stand is located in the laboratory engine room of the Maritime University of Gdynia. It is a dieselelectric unit consisting of an internal combustion engine cooperating with an electric generator. On the test stand it is possible to make a thermal balance of the engine and load characteristics. The stand has the UNITEST 201 diagnostic system, which enables electronic motor indication. It is also possible to analyze combustion and injection processes with simulated engine damage. Basic technical data are presented in Table 1.

Table 1. Characteristics of the SULZER 3AL25/30 engine

\begin{tabular}{|l|c|}
\hline Engine manufacture & Metal Industry Works H. Cegielski \\
\hline Type & 3AL25/20 \\
\hline Current type & Variable \\
\hline Electric voltage & $400 \mathrm{~V}$ \\
\hline Current frequency & $50 \mathrm{~Hz}$ \\
\hline Rotation speed & $750 \mathrm{rev} / \mathrm{min}$ \\
\hline Cylinder diameter & $250 \mathrm{~mm}$ \\
\hline Piston stroke & $300 \mathrm{~mm}$ \\
\hline Engine power & $396 \mathrm{~kW}$ \\
\hline
\end{tabular}

The SULZER 3AL25/20 engine shown in Figure 1 is a four-stroke self-ignition diesel engine, charged with a VTR 160 Brown-Boveri turbocharger. The air supercharging and the lubricating oil are cooled by means of a water system. The pistons are cooled with lubricating oil.

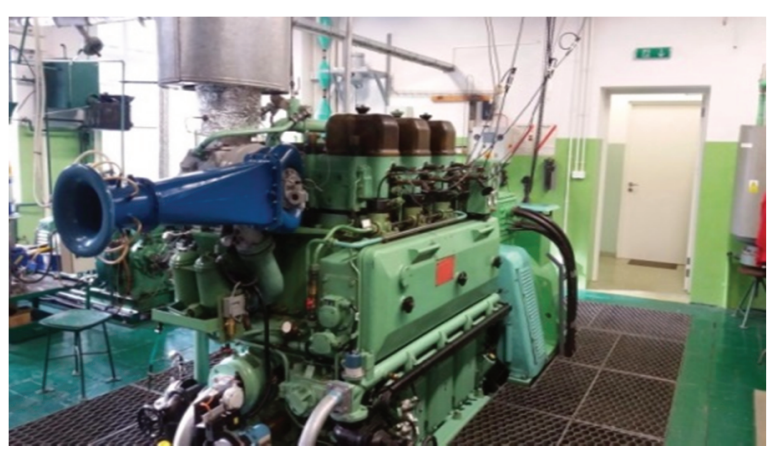

Fig. 1. SULZER 3AL25/30 engine

The UNITEST 201 diagnostic system is a computer engine monitoring system that is designed for continuous monitoring of motor and installation parameters.

The measurements were made for the following technical conditions of the engine:

- engine without damage at loads $50 \mathrm{~kW}, 120 \mathrm{~kW}, 200 \mathrm{~kW}$,

- damaged injection pump no. 2 (reduced fuel dose) at loads $50 \mathrm{~kW}, 120 \mathrm{~kW}, 200 \mathrm{~kW}$,

- damaged turbocharger - leakage in the intake system at loads $50 \mathrm{~kW}, 120 \mathrm{~kW}, 200 \mathrm{~kW}$.

During the tests EURODIESEL fuel was used for diesel engines in accordance with the European PN-EN 590 standard. Fuel properties are shown in Table 2.

Indicator diagrams were made with each engine load and technical condition (they were not included in this article), as well as the exhaust gas composition test with the MRU 95/3CD exhaust gas analyzer was carried out. 
Table 2. EURODIESEL fuel properties

\begin{tabular}{|c|l|c|c|}
\hline No. & Parameters & Value & Unit \\
\hline 1. & Density in temp. $15^{\circ} \mathrm{C}$ & 0.8287 & $\mathrm{~g} / \mathrm{cm}^{3}$ \\
\hline 2. & Kinematic viscosity in temp. $40^{\circ} \mathrm{C}$ & 2.789 & $\mathrm{~mm}^{2} / \mathrm{s}$ \\
\hline 3. & Cetane number & 51.0 & - \\
\hline 4. & Solid impurities content & 6 & $\mathrm{mg} / \mathrm{kg}$ \\
\hline 5. & Polycyclic aromatic hydrocarbons & 0.5 & $\%(\mathrm{~m} / \mathrm{m})$ \\
\hline 6. & Content of fatty acid esters & 7.0 & $\%(\mathrm{~V} / \mathrm{V})$ \\
\hline 7. & Calorific value of fuel & 42657 & $\mathrm{~kJ} / \mathrm{kg}$ \\
\hline 8. & Density of fuel & 828.7 & $\mathrm{~kg} / \mathrm{m}^{3}$ \\
\hline
\end{tabular}

\section{Exhaust gases analyzer type MRU 95/3CD}

The MRU 95/3CD type exhaust gas analyzer, shown in Fig. 2, is an electrochemical analyzer. It is mainly used in power plants, brickyards, laboratories, heating plants and in environments with high dustiness. The analyzer has such functions as:

- measurement of exhaust gas temperature up to $650^{\circ} \mathrm{C}$,

- ambient temperature up to $100^{\circ} \mathrm{C}$,

- content: $\mathrm{O}_{2}$ in the range of $0-21 \%, \mathrm{CO}$ in the range of $0-10000 \mathrm{ppm}, \mathrm{NO}_{\mathrm{x}}$ in the range of $0-4000 \mathrm{ppm}$ and $\mathrm{SO}_{2}$ in the range of $0-2000 \mathrm{ppm}$.

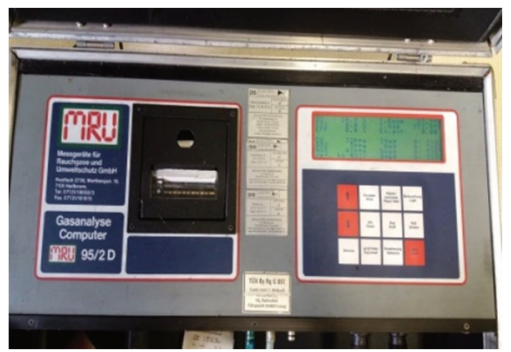

Fig. 2. Exhaust gases analyzer type MRU 95/3CD

\section{Principle of operation and description of the procedure for starting the exhaust gas analyzer}

The MRU 92/3CD analyzer was used for testing emissions of toxic compounds in exhaust gases. The principle of operation of the flue gas analyzer consists in generating electricity as a result of chemical reactions of the gas with the electrolyte. The gas is introduced into the electrolyte through a diffusion membrane. After completing the gas reaction with the electrolyte, the generated current is transferred to two separate electrodes included in two electrochemical sensors. The material type of electrodes, electrolyte and membranes depends on the type of gas detected by the sensor. Measurement results can be sent to a computer or printed in a built-in printer.

The analyzer used during measurements consists of two suitcases (gas preparation system and analyzer), enabling its transport and probes together with gas sampling lines. Before starting the tests, the calibration of the measuring device should be performed, consisting in examining the air composition in the laboratory.

\section{Test results}

\subsection{Oxygen content in the exhaust gases}

The oxygen content in the exhaust depends on the engine load (Table 3). The higher load causes the amount of oxygen in the exhaust gas decreases for operational state and simulated damage, where for a good condition falls from $15 \%$ to $12.5 \%$.
Table 3. The oxygen content in the exhaust gases

\begin{tabular}{|l|c|c|c|}
\hline \multicolumn{4}{|c|}{ Oxygen $\left(\mathrm{O}_{2}\right)$} \\
\hline Engine load & $50 \mathrm{~kW}$ & $120 \mathrm{~kW}$ & $200 \mathrm{~kW}$ \\
\hline Engine without damage & $15 \%$ & $13.7 \%$ & $12.5 \%$ \\
\hline $\begin{array}{l}\text { Damaged injection } \\
\text { pump No 2 }\end{array}$ & $15.4 \%$ & $13.9 \%$ & $12.3 \%$ \\
\hline $\begin{array}{l}\text { Air outlet in the } \\
\text { turbocharger }\end{array}$ & $15.3 \%$ & $13.3 \%$ & $11.5 \%$ \\
\hline
\end{tabular}

For the damaged injection pump and turbocharger the amount of oxygen in the exhaust gas is higher compared to the normal state, but then also decreases respectively from $15.4 \%$ to $12.3 \%$ and from $15.3 \%$ to $11.5 \%$.

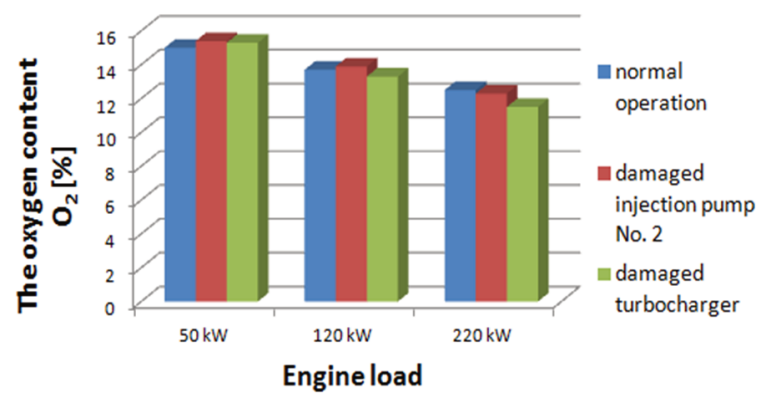

Fig. 3. The influence of the engine load on the oxygen $\mathrm{O}_{2}[\%]$ content indicated by the analyzer for various engine states

Figure 3 shows that the highest oxygen consumption occurs in the simulation of a damaged injection pump. The decreasing amount of oxygen is related to fuel consumption, which is lower for simulated malfunctions, for $50 \mathrm{~kW}$ and $120 \mathrm{~kW}$, while for the largest load, i.e. $220 \mathrm{~kW}$, the fuel consumption is at a similar level (Fig. 4).

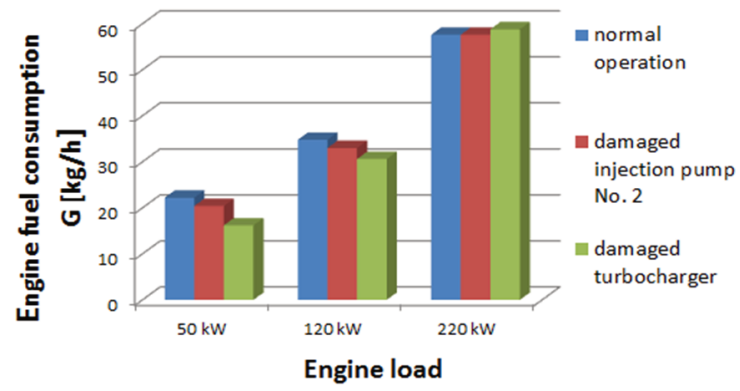

Fig. 4. Fuel consumption by a marine engine for three loads in different engine states

In addition, the composition of the fuel and air mixture affects the combustion process and the products of the combustion process. Depending on the conditions in which combustion takes place, complete and total combustion, incomplete and non-total combustion occur. Typically, due to imperfect combustion conditions, which will also occur in the event of engine damage, the products contain flammable substances, i.e. flammable gases in the case of incomplete combustion and solid combustible components in the case of non-total combustion [2,3]. The essential toxic components of exhaust gases include: carbon monoxide (CO), unburnt hydrocarbons (HC ) and nitrogen oxides $\left(\mathrm{NO}_{\mathrm{x}}\right)$. In addition, PM particulate matter are also formed, mainly in self-ignition engines [4]. 


\subsection{The carbon monoxide content in the exhaust gases}

The content of carbon monoxide (CO) in the exhaust gas tends to increase with increasing load and for the normal state increases from $651 \mathrm{ppm}$ to $1471 \mathrm{ppm}$ (Table 4).

Table 4. The carbon monoxide content in the exhaust gases

\begin{tabular}{|l|c|c|c|}
\hline \multicolumn{4}{|c|}{ Carbon monoxide (CO) } \\
\hline Engine load & $50 \mathrm{~kW}$ & $120 \mathrm{~kW}$ & $200 \mathrm{~kW}$ \\
\hline Engine without damage & $651 \mathrm{ppm}$ & $967 \mathrm{ppm}$ & $1471 \mathrm{ppm}$ \\
\hline $\begin{array}{l}\text { Damaged injection pump } \\
\text { No 2 }\end{array}$ & $773 \mathrm{ppm}$ & $1038 \mathrm{ppm}$ & $1653 \mathrm{ppm}$ \\
\hline $\begin{array}{l}\text { Air outlet in the } \\
\text { turbocharger }\end{array}$ & $753 \mathrm{ppm}$ & $1137 \mathrm{ppm}$ & $2108 \mathrm{ppm}$ \\
\hline
\end{tabular}

According to what was written above, the state of disability is conducive to the formation of incomplete combustion components, which include carbon monoxide. For example, for a damaged injection pump, the amount of carbon monoxide was more than 200 ppm higher than for a normal state at the same load.

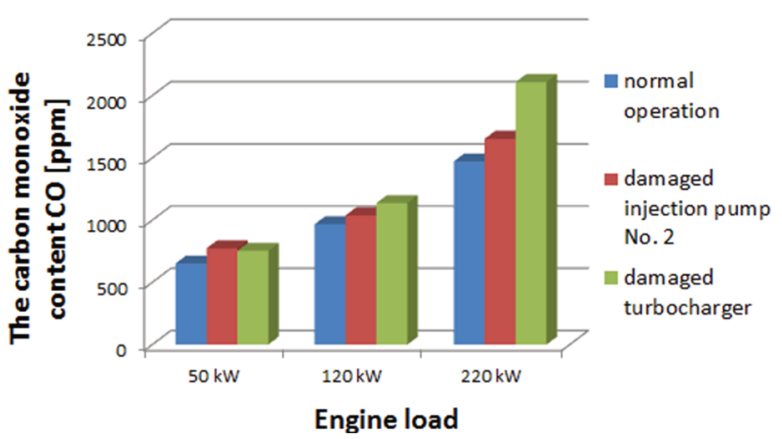

Fig. 5. The influence of engine load on the carbon monoxide CO [ppm] content indicated by the analyzer for various engine states

However, for the damaged turbocharger the increase in carbon monoxides was almost threefold (Fig. 5). Such results clearly indicate the occurrence of damage to engine components.

\subsection{The nitrogen oxides content in the exhaust gases}

As in previous cases, the increase of nitrogen oxides $\left(\mathrm{NO}_{\mathrm{x}}\right)$ in the exhaust gases is caused by the increase in engine load (Table 5) and additionally by the higher and higher exhaust gases temperature.

Table 5. The nitrogen oxides content in the exhaust gases

\begin{tabular}{|l|c|c|c|}
\hline \multicolumn{4}{|c|}{ Nitrogen oxides $\left(\mathrm{NO}_{\mathrm{x}}\right)$} \\
\hline Engine load & $50 \mathrm{~kW}$ & $120 \mathrm{~kW}$ & $200 \mathrm{~kW}$ \\
\hline Engine without damage & $700 \mathrm{ppm}$ & $1130 \mathrm{ppm}$ & $1201 \mathrm{ppm}$ \\
\hline $\begin{array}{l}\text { Damaged injection } \\
\text { pump No 2 }\end{array}$ & $820 \mathrm{ppm}$ & $1179 \mathrm{ppm}$ & $1271 \mathrm{ppm}$ \\
\hline $\begin{array}{l}\text { Air outlet in the } \\
\text { turbocharger }\end{array}$ & $842 \mathrm{ppm}$ & $1289 \mathrm{ppm}$ & $1362 \mathrm{ppm}$ \\
\hline
\end{tabular}

The increase in temperature is influenced by both the increasing load and the states of engine failure. In addition, it can be seen (Fig. 6) that damage to the turbocharger has a greater influence on the increase of this temperature than the faulty injection pump.

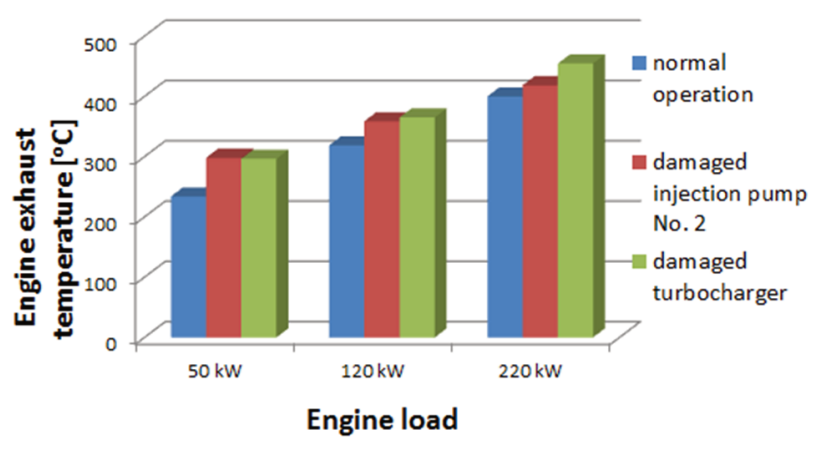

Fig. 6. Engine exhaust temperature 3AL25/30

The graph presented in Figure 7 shows that a larger impact on the growth of nitrogen oxides has a damaged turbocharger than an injection pump, i.e. similar to an increase in the exhaust gas temperature.

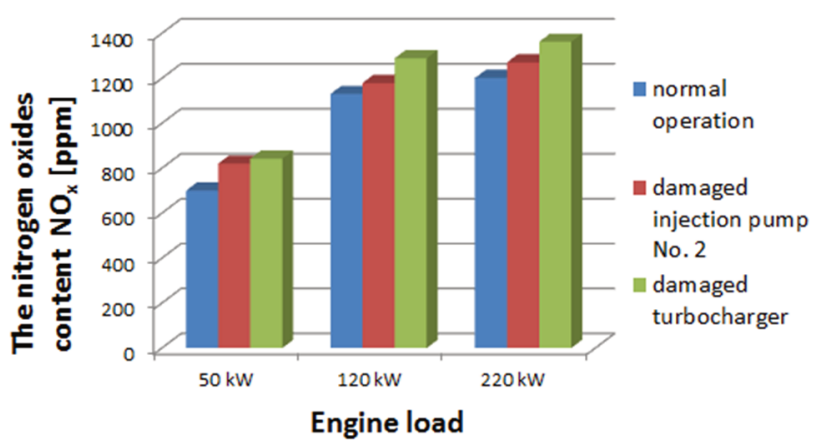

Fig. 7. The influence of engine load on the content of nitrogen oxides $\mathrm{NO}_{\mathrm{x}}$ [ppm] indicated by the analyzer for various engine states

Engine failure conditions also affect the increase of nitrogen oxides and for example at $200 \mathrm{~kW}$, the content of this compound increased from $1201 \mathrm{ppm}$ to $1271 \mathrm{ppm}$ for a damaged pump and up to $1362 \mathrm{ppm}$ for turbocharger malfunctions.

\subsection{The carbon dioxide content in the exhaust gases}

As for the content of carbon dioxide in the exhaust, it also increases depending on the load increase, but compared to other states, there are no such differences (Table 6).

Table 6. The carbon dioxide content in the exhaust gases

\begin{tabular}{|l|c|c|c|}
\hline \multicolumn{4}{|c|}{ Carbon dioxide $\left(\mathrm{CO}_{2}\right)$} \\
\hline Engine load & $50 \mathrm{~kW}$ & $120 \mathrm{~kW}$ & $200 \mathrm{~kW}$ \\
\hline $\begin{array}{l}\text { Engine without } \\
\text { damage }\end{array}$ & $4.3 \%$ & $5.3 \%$ & $6.2 \%$ \\
\hline $\begin{array}{l}\text { Damaged injection } \\
\text { pump No 2 }\end{array}$ & $4 \%$ & $5.1 \%$ & $6.3 \%$ \\
\hline $\begin{array}{l}\text { Air outlet in the } \\
\text { turbocharger }\end{array}$ & $4.4 \%$ & $5.6 \%$ & $6.9 \%$ \\
\hline
\end{tabular}

These similar values may be due to the fact that there is a greater increase in carbon monoxide as a result of incomplete combustion. On the other hand, imperfect combustion conditions affect the level of carbon dioxide, which has not been created as much as in the case of complete combustion (Fig. 8). 


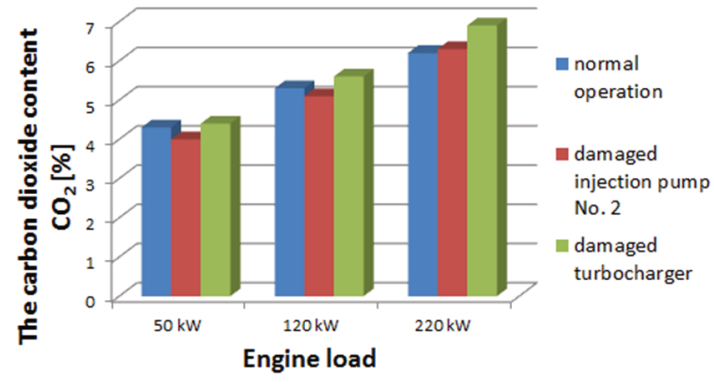

Fig. 8. The influence of engine load on the content of carbon dioxide $\mathrm{CO}_{2}$ $[\%]$ indicated by the analyzer for various engine states

\section{Conlusions}

The aim of the research was to assess the technical condition of the 3AL25/30 marine engine based on the analysis of the exhaust gases chemical composition. After analyzing the obtained results, it can be concluded that after using simulated malfunctions of the 3AL 25/30 engine, we get different results, which indicate the inefficiency of the combustion engine operation. It follows that the analysis of the exhaust gas composition can be used to assess the technical condition of the engine. The content of each of the compounds contained in the exhaust gases clearly differed in the states of disability in comparison to the normal state, i.e. there was a noticeable increase in the proportion of particles in the exhaust gases depending on the engine failure and load. The composition of the exhaust gases is affected by the pressure and temperature in the combustion chamber, and thus the engine load.

The flue gas analyzer also has the option of measuring the sulfur dioxide content. However, due to the fact that the marine engine was powered by marine diesel oil (MDO), which does not contain sulfur in the chemical composition, no readings of this compound were made.

The obtained results allow to evaluate this state, nevertheless marine engine diagnostics based on analysis of the composition of the exhaust gases during operation of the vessel is rarely used. In order to have a full spectrum of the technical condition of the engine, it is necessary to compare these results with fuel consumption, exhaust gas temperature, as well as with engine indicator diagrams made simultaneously with the exhaust composition measurements. Such graphs were made during the research, but they were not included in the article.

\section{Nomenclature}

$\mathrm{C}_{\mathrm{n}} \mathrm{H}_{\mathrm{m}}$ hydrocarbons

$\mathrm{CO}$ carbon monoxide

$\mathrm{CO}_{2}$, carbon dioxide

DO diesel oil

$\mathrm{NO}_{\mathrm{x}}$ nitrogen oxides
$\mathrm{O}_{2} \quad$ oxygen

PM particulate matter

RCHO aldehydes

SCR selective catalytic reduction

$\mathrm{SO}_{\mathrm{x}} \quad$ sulphur oxides

\section{Bibliography}

[1] BOCHEŃSKI, C., JANISZEWSKI, T. Diagnostyka silników wysokoprężnych. Wydawnictwa Komunikacji $i$ Łączności. Warszawa 1996.

[2] BORKOWSKI, T. Emisja spalin przez silniki okrętowe. Fundacja Rozwoju Wyższej Szkoły Morskiej w Szczecinie. Szczecin 1999.

[3] GIERNALCZYK, M. Metody redukcji emisji do atmosfery związków toksycznych oraz $\mathrm{CO}_{2}$ przez statki. Logistyka. 2014, 6, 655-665.

[4] GOLA, M., JANUŁA, J., LITWIN, J. Laboratorium Silników Spalinowych: Red. A. Kowalewicz. Wydawnictwo Politechniki Radomskiej. Radom 1996.

[5] KLUJ, S. Diagnostyka urządzeń okrętowych. Studium Doskonalenia Kadr S.C. Wyższej Szkoty Morskiej. Gdynia 1995.

[6] KOŁWZAN, K., ADAMKIEWICZ, A. Zapobieganie zanieczyszczeniu powietrza przez statki $\mathrm{w}$ świetle najnowszych wymagań Załącznika VI do Konwencji MARPOL. Zeszyty Naukowe Akademii Morskiej w Szczecinie. 2009, 18(90), 66-70.

[7] KOWALSKI, J. Ocena stężenia tlenków azotu w gazach wylotowych silnika okrętowego za pomocą sztucznej sieci neuronowej. Zeszyty Naukowe Akademii Morskiej w Gdyni. 2009, 60, 73-83.

[8] MERKISZ, J. Ekologiczne problemy silników spalinowych. Tom I. Wydawnictwo Politechniki Poznańskiej. Poznań 1998.

[9] USTRZYCKI, A. Laboratorium silników spalinowych. Ocena procesu spalania na podstawie wykresu indykatorowego. Wydawnictwo Politechniki Rzeszowskiej. Rzeszów 2011.

[10] WITKOWSKI, K. Stan diagnostyki technicznej okrętowych silników tłokowych. Diagnostyka. 2005, 34, 85-92.

[11] PIOTROWSKI, I., Witkowski K., Okrętowe silniki spalinowe. Trademar. Gdynia 2003.

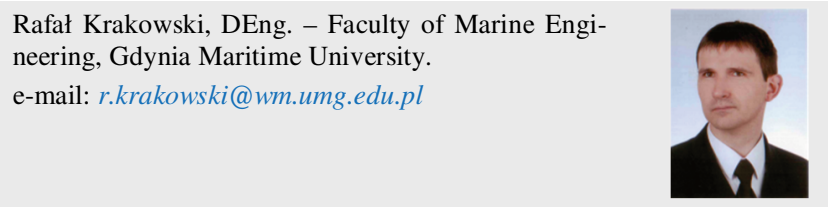

